UDC 621.396 .96

\title{
BLOCK DIAGRAM OF A MULTI-FREQUENCY RADIOMETRIC COMPLEX FOR UAV DETECTION IN DIFFERENT METEOROLOGICAL CONDITIONS
}

\author{
Nikolay V. Ruzhentsev, Simeon S. Zhyla, Vladimir V. Pavlikov, Gleb S. Cherepnin, \\ Eduard O. Tserne, Anatoliy V. Popov, Anton D. Sobkolov \\ National Aerospace University "Kharkiv Aviation Institure”, Kharkiv, Ukraine
}

Background. Technologies for the production of unmanned aerial vehicles (UAVs) of various classes are rapidly developing in Ukraine and the world. Small in terms of weight and dimensions and almost invisible for most information and measurement systems, UAVs began to be used in various industries - from the national economy to multimedia and advertising. Together with their useful application, new dangers and incidents have appeared - a collision of UAVs with people, structures, cultural monuments, the transportation of criminal goods, terrorist acts, flights over prohibited areas and within airports. UAV detection and control of their movement in populated areas and near critical objects are becoming one of the most important tasks of air traffic control services. The existing systems of the optical, acoustic and radar ranges cannot effectively perform such tasks in difficult meteorological conditions. As an addition to the already developed detection systems, it is proposed to use radiometric systems that register the UAV's own radio-thermal radiation. The authors have developed the theoretical foundations for the construction of multifrequency complexes necessary for the specification of their structural schemes.

Objective. The purpose of the paper is development of a scheme for a multi-frequency radiometric complex for detecting UAVs in different meteorological conditions based on optimal algorithms.

Methods. Analysis of the experience in the development of radiometric systems and methods for dealing with fluctuations in the gain of receivers, optimal operations for processing signals of intrinsic radio-thermal radiation, investigations of the probabilistic characteristics of detection and analysis of the domestic market of microwave technology developers will make it possible to develop a scheme of a multifrequency radiometric complex that will perform reliable measurements in various meteorological conditions.

Results. A block diagram of a four-frequency radiometric complex is proposed, which can be implemented in practice and is capable of performing reliable measurements in various meteorological conditions. The frequencies $10 \mathrm{GHz}, 20 \mathrm{GHz}, 35$ $\mathrm{GHz}$, and $94 \mathrm{GHz}$ were chosen as the resonant frequencies for tuning the radiometric receivers. For a given design and characteristics of receivers, the probabilities of detecting a UAV were calculated depending on the range of its flight.

Conclusions. From the results of the analysis of the existing achievements in the development of radiometric systems in Ukraine and the elemental base of microwave components available on the market, it follows that the $\mathrm{Ku}$ and $\mathrm{K}$ bands have the worst characteristics of spatial resolution, but are all-weather. The Ka and $\mathrm{W}$ bands are highly sensitive to radio-thermal radiation against the background of a clear sky, but are completely "blind" in a cloudy atmosphere and in rain. The results of calculating the detection ranges with a probability of 0.9 lie in the range from 1 to $3 \mathrm{~km}$, depending on the condition of the atmosphere. These results coincide with the known detection ranges of optical, acoustic and radar systems, but the selected parameters of the receivers do not correspond to potential world achievements and can be improved.

Keywords: radiometry; UAV detection; block diagram; detection range.

\section{Introduction}

The fast developing of unmanned aerial vehicles and their wide application in military conflicts, geodesy and cartography, agriculture, media make new demands to developing methods of counteraction, improvement of existing and creation of new methods and means of detection, ranging and eliminating unregistered UAVs.

When developing and modernizing modern airspace control facilities the main attention is paid to the development of acoustic, optical, infrared and radar methods. Each method has its own advantages and disadvantages, but they are united by the fact that at the same time research is underway to develop methods and means of reducing the signature in the specified ranges. As a result, a contradiction arises: on the one hand, the developers of means for detecting and combating UAVs are constantly increasing the accuracy and reliability of measurements, and on the other hand to the time of obtaining the results, they are already outdated and not relevant in relation to the developed means of reducing the visibility. This 
contradiction can be overcome through the use of devices and systems of passive radio heat location. Such systems are hidden, supersensitive and capable of registering the own radio-thermal radiation of aircraft, including those made of composite materials, in a wide spectrum of frequencies against the background of atmospheric radiation in any weather, day and night.

Signals of radio-thermal radiation are random and can be described by normal distribution. There are some classical works [1-6] of detecting noise on the background of noise and theoretical results [7-10] of signal processing methods optimization for radiometric systems improvement. Taking into account these results and practical recommendations [11-16] of radiometer receivers design it is necessary to develop practical recommendations for the construction of radiometric systems for detecting UAVs against the background of the atmosphere.

\section{Previous theoretical results}

To develop new passive radar of UAV detection it was stated following optimization problem: it is necessary, according to the received observations $u(t)$ to make a decision over the time interval $t \in[0, T]$ whether an increase in the useful signal $s_{U A V}(t)$ has appeared at the receiver input or there is a constant background signal $s_{\text {atm }}(t)$ mixed with the receiver noise $n(t)$.

The vector observation equation describing the signals at the input of the multifrequency radiometric complex on the time interval $(0, T)$ has the form

$$
\vec{u}(t)=\varepsilon \vec{s}_{U A V}(t)+\vec{s}_{a t m}(t)+\vec{n}(t),
$$

where $\varepsilon=(0,1)$ is the multiplier indicating the presence and absence of an increase in radio-thermal radiation, $\vec{s}_{U A V}(t)$ is the vector of useful noise signals from the desired UAV, $\vec{s}_{a t m}(t)$ is the atmospheric background radiation signal vector, $\vec{n}(t)$ is the vector of additive noise. Several frequencies for receiving UAV's own radio-thermal radiation were chosen in the $\mathrm{X}, \mathrm{Ku}, \mathrm{Ka}$ and $\mathrm{W}$ wave bands. In cloudless and clear weather, radiometric measurements in the $\mathrm{W}$ range will provide high-precision estimates of the spatial position of UAVs, in the $\mathrm{X}$ and $\mathrm{Ku}$ ranges - reliable observations in rain, snow, mist, fog, and the Ka range increases overall fluctuation radiometric complex.

The processes $s_{i U A V}(t), s_{\text {iatm }}(t), n_{i}(t)$ for each $i$-th frequency $(i=\overline{1, K})$ are Gaussian white (deltacorrelated) stationary and mutually independent random processes with zero mean. optimal observation $\vec{u}(t)$ processing system), it was used the criterion of the likelihood function ratio:

$$
\frac{P(\vec{u}(t) \mid 1)}{P(\vec{u}(t) \mid 0)}>\text {, or }<\frac{P(0)}{P(1)},
$$

where

$$
P(\vec{u}(t) \mid \varepsilon=1)=P(\vec{u}(t) \mid 1)
$$

$P(\vec{u}(t) \mid \varepsilon=0)=P(\vec{u}(t) \mid 0)$ are likelihood functions, $P(0)$ and $P(1)$ are a priori probabilities of the absence and presence of a UAV in the observation area.

The obtained optimal detection method is as follows

$$
Y=\sum_{i=1}^{K} C_{i} \int_{0}^{T} u_{i}^{2}(t) d t>\text {, or }<Y_{0},
$$

where $Y$ is the optimal detector output effect, $Y_{0}$ is the output effect threshold,

$$
C_{i}=\frac{T_{i U A V}}{k_{B}\left(T_{i_{a t m}}+T_{i n}\right)\left(T_{i U A V}+T_{i_{a t m}}+T_{i n}\right)},
$$

$k_{B}$ is the Boltzmann constant, $T_{i U A V}, T_{i \text { atm }}, T_{i n}$ are brightness temperatures of the UAV, background radiation of the atmosphere, internal noise of the receiver.

\section{Block diagram of the radiometric complex}

The main operations in algorithm (3) are the formation of estimates of the energies of the received oscillations $u_{i}(t)$ and weight averaging of these estimates taking into account the characteristics of the receivers and the brightness temperatures of the UAV and the atmosphere in different frequency ranges. Weight averaging with defined coefficients $C_{i}$ is a new optimal operation. At the same time, the operation of energy estimation by the energy receiver was investigated in [1-5]. Over the past 50 years, a number of practical recommendations [6-16] for the construction of energy receivers and the development of additional measures to obtain effective and unbiased estimates of the parameters of radio thermal sources were proposed. Such operations should include modulation of useful signals to the receiver input, periodic calibration of receivers, thermal stabilization of input paths. Taking into account the experience of developing radiometric receivers, a structural diagram of the radiometric complex is proposed, which is shown in Fig. 1.

The radiometric complex works as follows. Any matter with a temperature above zero Kelvin emits its own radio-thermal radiation, the magnitude of which can be described in units of luminosity temperature. Usually anthropogenic sources of radiothermal radiation have a brightness temperature higher than the brightness temperature of the sky and can be detected 
antenna 1 receives radio thermal radiation. Antenna 1 focuses the radiation in the area where $\mathrm{N}$ irradiators are placed. These irradiators in each channel implement a parallel view of the space and increase the observation time of the source of radio thermal radiation. Increasing the observation time leads to an increase in the detection range of sources of radio thermal radiation against the sky. From the output of the irradiators 2 signals are modulated in N PIN diode modulators 3, amplified in $\mathrm{N}$ broadband low-noise amplifiers 4 and detected in $\mathrm{N}$ square detectors 5. Modulation is required to further compensate in the intelligent processor 9 for the impact of flicker noise on the measurement results. PIN diode modulator 3 periodically closes the input path of the receiver and is controlled by the meander signal from the output of the control generator 8 . After detectors 5 signals in each of the $\mathrm{M}$ channels are converted into digital form by ADC 6. After presenting signals of different channels in digital form, flicker noise and inter-channel integration in the digital information processing unit 7 in the form of weight summation with coefficients. To filter from flicker noise measurement results, digital signals based on the signal from the control generator 8 are divided into half-cycles. In the first half, there is a signal that is proportional to the sum of the brightness temperatures of the source of radio thermal radiation and internal noise, which are distorted by flicker noise. In the second half of the modulation, only the signal from internal noise is observed, which is also distorted by flicker noise. In the digital information processing unit 7 , the division of luminance temperature estimates for different modulation periods is performed. To determine the true value of the brightness temperature of a source of radio thermal radiation, it is necessary to know the brightness temperature of internal noise. Fully stationary and reliable measurements can be obtained when the brightness temperature of internal noise is constant over time. For this purpose, the structure of the radiometric complex provides a thermal stabilization unit 14, which covers the input path - all PIN diode modulators 3 and broadband low-noise amplifiers 4 . The measured temperature in the middle of the thermal stabilization unit 14 is fed to an intelligent processor 9. Thermal stabilization 14 and outputs control signals to the unit 14. The results of weight summation of data from different channels are fed to the intelligent processor 9 to decide on the presence or absence of a source of radio thermal radiation in the observation area. Processing in the intelligent processor 9 can be performed by optimal algorithms or using modern methods of machine learning. To study the selected part of the sky in the structure of the complex provides controls 11, which adjust the viewing sector and scanning speed. The control signals are fed to the intelligent processor 9 and to the antenna-rotary device 12 , which implements the mechanical movement of the pattern of the antennas in space. The current value of the rotation angles of the antenna-rotary device 12 by angle and azimuth is registered by the angle sensor 13. Signals from the angle sensors enter the intelligent processor 9, where taking into account the specified sector, scanning speed provided by the controls 11 temperatures, a radiometric image of the observation zone is formed. The methods of image processing and compression are applied to the radiometric image in the intelligent processor 9.

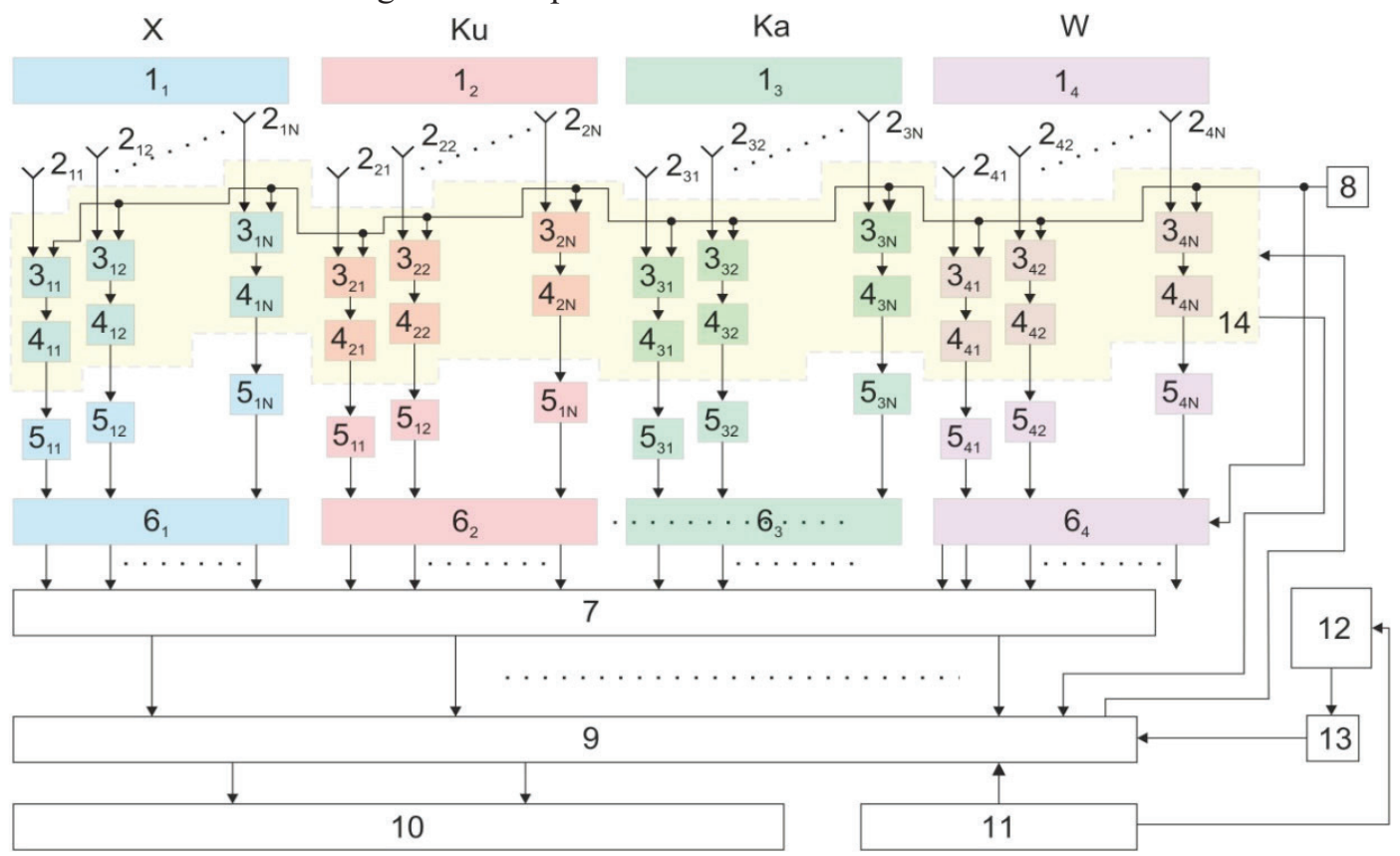

Fig.1. Block diagram of the radiometric complex of UAV detection 
To ensure all-weather in the complex, there are 2 channels for receiving its own radio-thermal radiation in the $\mathrm{Ku}$ and $\mathrm{K}$ wave bands, and to ensure high resolution - in the $\mathrm{W}$ wave range. The higher frequency bands have a significant attenuation of electromagnetic waves along the propagation path, while the lower frequency bands have cumbersome antenna systems and low resolution at angular coordinates. Between the bands $\mathrm{K}$ and $\mathrm{W}$ to increase the sensitivity of the radiometric complex and the reliability of UAV detection, it is also proposed to use a radiometric receiver Ka of the wavelength range.

\section{Probability of UAV correct detection in the background of the atmosphere signal generation}

In practice, the most interesting are the probability of correct detection $D\left(Y_{0}\right)=\int_{Y_{0}}^{\infty} P(Y \mid \varepsilon=1) d Y$ and the probability of false alarm $L\left(Y_{0}\right)=\int_{Y_{0}}^{\infty} P(Y \mid \varepsilon=0) d Y$. To determine them, it is necessary to find the differential laws of probability distribution $P(Y \mid \varepsilon=1), P(Y \mid \varepsilon=0)$

. In expression (7), the processes $u_{i}(t)$ at each frequency are distributed according to the normal law, and the values $u_{i}^{2}(t)$ according to the $\chi^{2}$ law, the values $\int_{0}^{T} u_{i}^{2}(t) d t$ according to the $\chi^{2}$ law with $M_{i}$ degrees of freedom. In practical situations of radiometric measurements, the number $M_{i}$ exceeds one million. Therefore, the output effect $Y$ (sufficient statistics) due to the central limit theorem of Lyapunov can be considered distributed according to the normal law

$$
P(Y)=\frac{1}{\sqrt{2 \pi} \sigma_{Y}} \exp \left(-\frac{\left(Y-m_{Y}\right)^{2}}{2 \sigma_{Y}^{2}}\right),
$$

where $m_{Y}$ is the men of the output effect $Y, \sigma_{Y}^{2}$ is the variance of $Y$.

For the stated optimization problem (8) has the following forms:

$$
P(Y \mid 0)=\frac{1}{\sqrt{2 \pi 0,5 k_{B}^{2} \sum_{i=1}^{K} M_{i} C_{i}^{2}\left(T_{i a t m}+T_{i n}\right)^{2}}} \times
$$

$$
\times \exp \left(-\frac{1}{2} \frac{\left(Y-0,5 k_{B} \sum_{i=1}^{K} M_{i} C_{i}\left(T_{i a t m}+T_{i n}\right)\right)^{2}}{0,5 k_{B}^{2} \sum_{i=1}^{K} M_{i} C_{i}^{2}\left(T_{i a t m}+T_{i n}\right)^{2}}\right),
$$

$$
\begin{gathered}
P(Y \mid 0)=\frac{1}{\sqrt{2 \pi \frac{k_{B}^{2}}{2} \sum_{i=1}^{K} M_{i} C_{i}^{2}\left(T_{i U A V}+T_{\text {a atm }}+T_{i n}\right)^{2}}} \times \\
\times \exp \left(-\frac{1}{2} \frac{\left(Y-\frac{1}{2} k_{B} \sum_{i=1}^{K} M_{i} C_{i}\left(T_{i U A V}+T_{i \text { atm }}+T_{i n}\right)\right)^{2}}{0,5 k_{B}^{2} \sum_{i=1}^{K} M_{i} C_{i}^{2}\left(T_{i U A V}+T_{i \text { atm }}+T_{i n}\right)^{2}}\right) .
\end{gathered}
$$

To calculate $L\left(Y_{0}\right)$ it is performed the following transformations

$$
\begin{aligned}
& L\left(Y_{0}\right)=\int_{Y_{0}}^{\infty} \frac{1}{\sqrt{2 \pi} \sigma_{Y}[Y(\vec{u} \mid 0)]} \mathrm{e}^{-\frac{\left(Y-m_{Y}[Y(\vec{u} \mid 0)]\right)^{2}}{2 \sigma_{Y}^{2}[Y(\vec{u} \mid 0)]}} d Y= \\
& =\left|\begin{array}{c}
x=\frac{Y-m_{Y}[Y(\vec{u} \mid 0)]}{\sigma_{Y}[Y(\vec{u} \mid 0)]}, d x=\frac{d Y}{\sigma_{Y}[Y(\vec{u} \mid 0)]}, \\
\text { for } Y=Y_{0}, \quad x=x_{0}=\frac{Y_{0}-m_{Y}[Y(\vec{u} \mid 0)]}{\sigma_{Y}[Y(\vec{u} \mid 0)]}
\end{array}\right|= \\
& =\frac{1}{\sqrt{2 \pi}} \int_{x_{0}}^{\infty} \exp \left(-\frac{x^{2}}{2}\right) d x=1-\frac{1}{\sqrt{2 \pi}} \int_{-\infty}^{x_{0}} \exp \left(-\frac{x^{2}}{2}\right) d x= \\
& =1-F\left(x_{0}\right)=F\left(-x_{0}\right)=\frac{1}{2}\left[1-\Phi\left(x_{0}\right)\right],
\end{aligned}
$$

where $F\left(x_{0}\right)$ and $\Phi\left(x_{0}\right)$ are probability integrals.

The probability of correct detection $D\left(Y_{0}\right)$ is also written as follows

$$
D\left(Y_{0}\right)=1-F\left(y_{0}\right)=F\left(-y_{0}\right)=\frac{1}{2}\left[1-\Phi\left(y_{0}\right)\right],
$$

where $y_{0}=\frac{Y_{0}-m_{Y}[Y(\vec{u} \mid 1)]}{\sigma_{Y}[Y(\vec{u} \mid 1)]}$.

\section{Calculation of probabilities of correct UAV detection}

The following investigations of the probabilities of UAV detection were performed for the following parameters:

- probability of false alarms: $10^{-2}, 10^{-3}, 10^{-4}$,

- central frequencies of receivers tuning: $f_{1}=11 \Gamma Г u, f_{2}=21 \Gamma \Gamma u, f_{3}=35 \Gamma Г u, f_{4}=94 Г Г ॅ$, 
- UAV category is the light UAVs,

- atmospheric condition: clear, cloudy, rain.

It has to be noted that the effect of fog, mist and smog on the probability of detection is negligible compared to clouds and precipitation in these frequency ranges.

Developments and components available on the Ukrainian market that will allow the development of budget radiometric receivers were used as radiometric receivers to study the potential characteristics of detection. In particular, a Ka-band radiometric receiver developed on the PJSC NPP "Saturn" [17], a State W radiometer from the State Enterprise RI "Orion" [18], $\mathrm{Ku}$ and $\mathrm{K}$ band satellite converters for satellite television were selected for analysis. These radiometric receivers and converters have the following characteristics:

- internal noise temperature of receivers: $100 \mathrm{~K}$ for frequency $f_{1}, 130 \mathrm{~K}$ for frequency $f_{2}, 600 \mathrm{~K}$ for frequency $f_{3}, 2000 \mathrm{~K}$ for frequency $f_{4}$,

- receiver bandwidth $\Delta f_{1}=1 \mathrm{GHz}, \Delta f_{2}=0,5 \mathrm{GHz}$, $\Delta f_{3}=4,5 \mathrm{GHz}, \Delta f_{4}=6 \mathrm{GHz}$.

- observation time constant $1 \mathrm{~s}$ for all receivers.

Calculations were performed for one $40^{\circ}$ sighting angle. For this angle, the brightness temperatures of the UAV, made of composite materials, have the following values: $86 \mathrm{~K}$ for frequency $f_{1}, 96 \mathrm{~K}$ for frequency $f_{2}$, $121 \mathrm{~K}$ for frequency $f_{3}, 247 \mathrm{~K}$ for frequency $f_{4}$.

To determine the curves of the correct detection of UAVs depending on the range in different weather conditions, a simulation program was developed in the MatLab package.

The results of calculating the probability curves are shown in Fig. 2-4.

Summary information on the range of detection of UAVs with a probability of 0.9 during a clear atmosphere, cloudy atmosphere and rain for $L=10^{-2}, L=10^{-3}, L=10^{-4}$ are given in Table 1 .

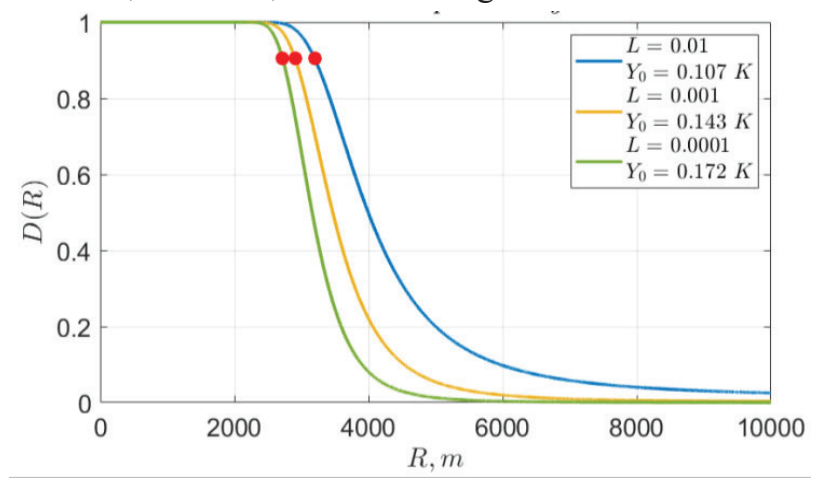

Fig.2. The probability of correct detection of UAVs against a clear atmosphere

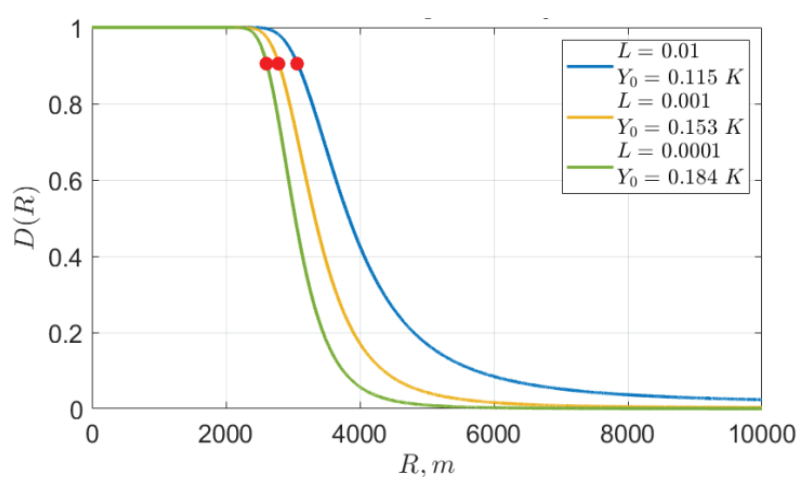

Fig.3. The probability of correct detection of UAVs against a cloudy atmosphere

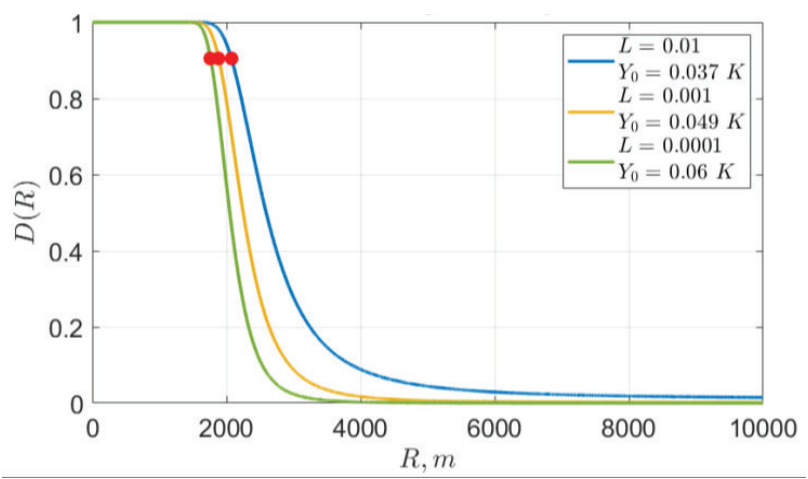

Fig.4. The probability of correct detection of UAVs in the rain

Table 1. UAV detection distances

\begin{tabular}{|c|c|c|c|}
\hline \multirow{2}{*}{$L$} & \multicolumn{3}{|c|}{ Atmospheric condition } \\
\cline { 2 - 4 } & Clear & Cloudy & Rain \\
\hline $10^{-2}$ & $3195 \mathrm{M}$ & $3069 \mathrm{M}$ & $1296 \mathrm{M}$ \\
\hline $10^{-3}$ & $2905 \mathrm{M}$ & $2790 \mathrm{M}$ & $1178 \mathrm{M}$ \\
\hline $10^{-4}$ & $2717 \mathrm{M}$ & $2610 \mathrm{M}$ & $1102 \mathrm{M}$ \\
\hline
\end{tabular}

The obtained results of calculating the range of reliable UAV detection have the same order as the detection range of advanced optical, radar and acoustic systems. At the same time the laid down characteristics of channels of radiometric receivers can be increased in case of use of an element base of world-class companies RPG-Radiometer Physics GmbH (RPG) Member of the ROHDE \& SCHWARZ group of companies [19], Pasternack Company [20], Millimeter Wave Products Inc. (Mi-Wave) [21]. Taking into account breakthrough results of microwave components developing it was calculated probability of correct detection of UAVs and defined limit detection distance of correct detection. All the obtained results are shown in Table 2. 
Table 2. UAV detection distances for high-quality passive radar microwave components

\begin{tabular}{|c|c|c|c|}
\hline \multirow{2}{*}{$L$} & \multicolumn{3}{|c|}{ Atmospheric condition } \\
\cline { 2 - 4 } & Clear & Cloudy & Rain \\
\hline $10^{-2}$ & $8200 \mathrm{M}$ & $8000 \mathrm{M}$ & $6800 \mathrm{M}$ \\
\hline $10^{-3}$ & $7450 \mathrm{M}$ & $7200 \mathrm{M}$ & $6150 \mathrm{M}$ \\
\hline $10^{-4}$ & $6970 \mathrm{M}$ & $6800 \mathrm{M}$ & $5700 \mathrm{M}$ \\
\hline
\end{tabular}

\section{Conclusion}

The results of the analysis of the existing achievements in the development of radiometric systems in Ukraine and the elemental base of microwave components available on the market, it follows that the $\mathrm{Ku}$ and $\mathrm{K}$ bands have the worst characteristics of spatial resolution, but are all-weather. The Ka and $\mathrm{W}$ bands are highly sensitive to radiothermal radiation against the background of a clear sky, but are completely "blind" in a cloudy atmosphere and in rain. The results of calculating the detection ranges with a probability of 0.9 lie in the range from 1 to $3 \mathrm{~km}$, depending on the condition of the atmosphere. These results coincide with the known detection ranges of optical, acoustic and radar systems, but the selected parameters of the receivers do not correspond to potential world achievements and can be improved. Taking into account results of microwave components developing in companies GmbH (RPG), Pasternack Company, Millimeter Wave Products Inc. the limit UAV detection distances were obtained. Such multifrequency radiometric complex can detect light UAVs in the range from 6 to $8 \mathrm{~km}$. These characteristics are good and promising for the following practical development and experimental investigation.

\section{References}

1. Nikolaiev, A.G., Pertsov, S.V. (1964) Radio-Thermal Location. Moscow:Sov. Radio, [in Russian]

2. Falkovich S. E., Ponomarev V. I., Shkvarko Yu. V.: Optimal reception of space-time signals in radio channels with scattering. Radio i svyaz, Moscow (1989) [in Russian]

3. Falkovich S. E., Kostenko P. Yu.: Fundamentals of the statistical theory of radio engineering systems: a tutorial. Kharkiv Aviation Institute, Kharkov (2005) [in Russian]

4. Falkovich S. E., Khomyakov E. N.: Statistical theory of radio measuring systems. Radio i svyaz, Moscow (1981) [in Russian]

5. Kotel'nikov, V. A.: The theory of optimum noise immunity. McGraw-Hill Book Co., New York (1959)

6. Shirman Ya. D., Manzhos V. N.: Theory and technique of processing radar information against the background of interference. Radio i svyaz, Moscow (1981) [in Russian]

7. V.V. Volosyuk, V. V. Pavlikov, N. V. Ruzhentsev, S. S. Zhyla, O. V. Odokienko, and A. D. Sobkolov. 2018. "Method of Detection of Thermal Microwave Radiation Increments.". doi:10.1109/UWBUSIS.2018.8520028.

8. Volosyuk, V. K., V. V. Pavlikov, S. S. Zhyla, and O. V. Odokienko. 2017. "Optimal Radiometric Detection of Band-Limited Noise Signal.". doi:10.1109/ELNANO.2017.7939805.

9. Volosyuk, V. K., V. F. Kravchenko, A. V. Odokienko, V. V. Pavlikov, and V. I. Pustovoit. 2018. "An Optimal Algorithm for the Formation of Unbiased Estimates of the Effective Noise Temperature of a Stochastic Radio Thermal Signal." Doklady Physics 63 (6): 227-230. doi:10.1134/S1028335818060034.

10. Volosyuk, V. K., S. S. Zhyla, V. V. Pavlikov, A. D. Abramov, and V. G. Yakovlev. 2018. "Optimum Algorithm for Estimating Radio Brightness in Spatially Distributed Radiometer Systems." Telecommunications and Radio Engineering (English Translation of Elektrosvyaz and Radiotekhnika) 77 (18): 1649-1658. doi:10.1615/TelecomRadEng.v77.i18.70.

11. Ulaby, F. T. Microwave Remote Sensing: Active and Passive, Vol. I-III / F. T. Ulaby, R. K. Moore, A. K. Fung. - Microwave Remote Sensing: Fundamentals and Radiometry, Addison-Wesley, Advanced Book Program, Reading, Massachusetts, 1981. $-456 \mathrm{p}$.

12. Shylo, S. A W-band passive imaging system implemented with rotating diffraction antenna technology / S. Shylo, Yu. Sydorenko, D. Wheeler, D. Dundonald // Proc. of SPIE. - 2013. - Vol. 8900.pp. $890008-1 \div 890010$.

13. Dicke, R. H. The Measurement of Thermal Radiation at Microwave Frequencies / R. H. Dicke // Review of Scientific Instruments. - 1946. - Vol. 17, - pp. 268-275.

14. Volosyuk V. K. Algorithms synthesis and potentiality analysis of optimum ultrawideband signal processing in the radiometric system with modulation / V. K. Volosyuk, V. V. Pavlikov, S. S. Zhyla // Antenna Theory and Technigues. ICATT'2011 : III Intern. conf., Sept. 20-23, 2011, Kiev, Ukraine. - [Kiev], 2011. pp. $235-237$.

15. Experimental results of gain fluctuations and noise in microwave low-noise cryogenic amplifiers / J. D. Gallego, I. Lopez-Fernandez, C. Diez, A. Barcia // Proc. SPIE. - 2004. - Vol. 5470. - pp. 402-413.

16. Churilov V. P. Investigation of locating polluted water surface areas possibilities by the radiometer method at the millimeter wave range / V. P. Churilov, N. V. Ruzhentsev, Yu. A. Kuz'menko // «Turkish journal of physics». - 1995. - Vol. 19, №8. - pp. 1069-1072.

17. PJSC NPP "Saturn"; Retrieved from http://www.jssaturn.com/

18. State Enterprise RI "Orion"; Retrieved from http://orion.org.ua/ 
19. RPG-Radiometer Physics GmbH (RPG); Retrieved from https://www.radiometer-physics.de/

20. Pasternack Company; Retrieved from https://www.pasternack.com/
21. Millimeter Wave Products Inc. (Mi-Wave); Retrieved from https://www.miwv.com/

\author{
Руженцев М.В., Жила С.С., Павліков В.В., Черепнін Г. С., Церне Е.О., Попов А.В., Собколов А.Д. \\ Структурна схема багаточастотного радіометричного комплексу виявлення БПЛА в різних \\ метеорологічних умовах
}

Проблематика. В Україні та світі набули стрімкого розвитку технології виробництва безпілотних літальних апаратів (БПЛА) різного класу. Малі за масо-габаритними характеристиками та майже невидимі для більшості інформаційно-вимірювальних систем БПЛА стали використовуватись в різних галузях - від народного господарства до мультимедіа та реклами. Разом з корисним їх використанням з'явились нові небезпеки та інциденти - зіткнення БПЛА з людьми, спорудами, пам'ятниками культури, перевезення кримінальних товарів, терористичні акти, польоти над забороненими ділянками та в межах аеропортів. Виявлення БПЛА та контроль їх переміщення у населених пунктів та поблизу критичних об'єктів стає однією з найважливіших задач служб контролю руху повітряним простором. Існуючі системи оптичного, акустичного та радіолокаційного діапазонів не спроможні ефективно виконувати такі задачі в складних метеорологічних умовах. У якості доповнення до вже розвинутих систем виявлення пропонується використовувати радіометричні системи, що реєструють власне радіотеплове випромінювання БПЛА. Авторами були розроблені теоретичні основи побудови багаточастотних комплексів, необхідні для конкретизації їх структурних схем.

Мета досліджень. Розробка схеми багаточастотного радіометричного комплексу виявлення БПЛА в різних метеорологічних умовах на основі оптимальних алгоритмів.

Методика реалізації. Аналіз досвіду розробки радіометричних систем та методів боротьби 3 флуктуаціями коефіцієнту підсилення приймачів, оптимальні операції обробки сигналів власного радіотеплового випромінювання, дослідження ймовірнісних характеристик виявлення та аналіз вітчизняного ринку розробників НВЧ техніки дозволять розробити схему багаточастотного радіометричного комплексу, що виконуватиме надійні вимірювання в різних метеорологічних умовах.

Результати досліджень. Запропоновано структурну схему чотирьохчастотного радіометричного комплексу, що може бути реалізований на практиці та здатний виконувати надійні вимірювання в різних метеорологічних умовах. У якості резонансних частот налаштування радіометричних приймачів були обрані частоти 10 ГГц, 20 ГГц, 35 ГГц і 94 ГГц. Для заданої конструкції та характеристик приймачів розраховані ймовірності виявлення БПЛА в залежності від дальності його польоту.

Висновки. 3 результатів аналізу існуючих досягнень розвитку радіометричних систем в Україні та наявної на ринку елементної бази мікрохвильових компонентів випливає, що діапазон $\mathrm{Ku}$ та $\mathrm{K}$ має найгірші характеристики просторової роздільної здатності, але є всепогодними. Діапазони Ка i W мають високу чутливість до радіотеплового випромінювання на тлі ясного неба, але вони повністю «сліпі» при хмарній атмосфері та в дощ. Результати розрахунку відстаней виявлення з імовірністю 0,9 лежать у діапазоні від 1 до 3 кілометрів в залежності від стану атмосфери. Ці результати збігаються з відомими дальностями виявлення оптичних, акустичних та радіолокаційних систем, але при цьому обрані параметри приймачів не відповідають потенційним світовим досягненням і можуть бути покращені.

Ключові слова: радіометрія; виявлення БПЛА; структурна схема; дальність виявлення.

\title{
Руженцев Н.В., Жила С.С., Павликов В.В., Черепнин Г. С., Цернэ Е.О., Попов А.В., Собколов А.Д.
}

Структурная схема многочастотного радиометрического комплекса обнаружения БПЛА в разных метеорологических условиях

Проблематика. В Украине и мире стремительно развиваются технологии производства беспилотных летательных аппаратов (БПЛА) разного класса. Малые по массогабаритным характеристикам и почти невидимые для большинства информационно-измерительных систем БПЛА стали использоваться в разных отраслях - от народного хозяйства до мультимедиа и рекламы. Вместе с полезным их использованием появились новые опасности и инциденты столкновение БПЛА с людьми, сооружениями, памятниками культуры, перевозка криминальных товаров, террористические акты, полеты над запрещенными территориями и в пределах аэропортов. Выявление БПЛА и контроль их перемещения в населенных пунктах и вблизи критических объектов становятся одной из важнейших задач служб контроля движения воздушным пространством. Существующие системы оптического, акустического и радиолокационного диапазонов не могут эффективно выполнять такие задачи в сложных метеорологических условиях. В качестве дополнения к уже развитым системам обнаружения предлагается использовать радиометрические системы, регистрирующие собственное радиотепловое излучение БПЛА. Авторами были 
разработаны теоретические основы построения многочастотных комплексов, необходимых для конкретизации их структурных схем.

Цель исследований. Разработка схемы многочастотного радиометрического комплекса обнаружения БПЛА в разных метеорологических условиях на основе оптимальных алгоритмов.

Методика реализации. Анализ опыта разработки радиометрических систем и методов борьбы с флуктуациями коэффициента усиления приемников, оптимальные операции обработки сигналов собственного радиотеплового излучения, исследования вероятностных характеристик обнаружения и анализ отечественного рынка разработчиков СВЧ техники позволят разработать схему многочастотного радиометрического комплекса, которая будет выполнять надежные измерения в различных метеорологических условиях.

Результаты исследований. Предложена структурная схема четырехчастотного радиометрического комплекса, которая может быть реализована на практике и способна выполнять надежные измерения в различных метеорологических условиях. В качестве резонансных частот настройки радиометрических приемников были выбраны частоты 10 ГГц, 20 ГГц, 35 ГГц и 94 ГГц. Для данной конструкции и характеристик приемников рассчитаны вероятности обнаружения БПЛА в зависимости от дальности его полета.

Выводы. Из результатов анализа существующих достижений развития радиометрических систем в Украине и имеющейся на рынке элементной базы микроволновых компонентов следует, что диапазоны Ки и К имеет наихудшие характеристики пространственного разрешения, но являются всепогодными. Диапазоны Ка и W обладают высокой чувствительностью к радиотепловому излучению на фоне ясного неба, но полностью «слепы» при облачной атмосфере и в дождь. Результаты расчета дальностей обнаружения с вероятностью 0,9 лежат в диапазоне от 1 до 3 км в зависимости от состояния атмосферы. Эти результаты совпадают с известными дальностями обнаружения оптических, акустических и радиолокационных систем, но при этом выбранные параметры приемников не соответствуют потенциальным мировым достижениям и могут быть улучшены.

Ключевые слова: радиометрия; обнаружение БПЛА; структурная схема; дальность обнаружения. 